\title{
REVIEW
}

\section{Time-lag algal growth dynamics: biological constraints on primary production in aquatic environments}

\author{
Yves Collos \\ Centre de Recherche en Ecologie Marine et Aquaculture de L'Houmeau, Case 5, F-17137 Nieul-sur-Mer, France
}

\begin{abstract}
Changes in the nutrient regime of phytoplankton cells induce variable time lags before the onset of cell division (quasi-instantaneous response to more than $24 \mathrm{~h}$ lags), dependent mainly on the algal species and the magnitude of the nutrient pulse. The latter parameter appears to be a main controlling factor in algal growth dynamics under transient conditions, overriding other variables such as temperature, irradiance and nutritional state. The presence of such phenomena puts intrinsic limits on primary production in a variable nutrient environment because algal cells are not made up of synthetic components only (sensu Williams 1971), but also of structural and genetic material. Under these conditions, high nutrient uptake rates over short time periods do not necessarily lead to high growth rates (defined as increase in cell numbers) over comparable time scales, even if cell quota increase very rapidly following nutrient resupply. Data from different groups of investigators on uptake-growth coupling, internal nutrient pools, growth lag, and carbon-nitrogen uptake interactions show consistent patterns as follows: for phytoplankton in a variable nutrient environment, 2 essential strategies emerge at the genus level. One is the 'growth' response, exhibited by the genera Dunaliella and Chaetoceros, which do not accumulate internal pools of inorganic nutrients, whose uptake and growth are closely coupled, and which therefore process nutrient pulses very rapidly into new cells. The other is the 'storage' response, found in genera such as Thalassiosira or Amphidinium, which have the capability of accumulating large internal nutrient pools, present extensive uncoupling between uptake and growth, and exhibit lags in cell division of up to $24 \mathrm{~h}$ following a single addition of the limiting nutrient. The latter response type presents an ecological advantage when nutrient pulsing frequency is lower than cell division rate; the first response type would provide a competitive advantage at high frequency pulses.
\end{abstract}

\section{INTRODUCTION}

Although the significance of elevated nutrient uptake by phytoplankton in a nutrient-poor and patchy environment has been subject of much debate (Lehman \& Scavia 1982, 1984, Currie 1984a, b, Goldman $1984 \mathrm{a}, \mathrm{b})$, the relation of this phenomenon to algal cell growth has been much less studied. Algal cells can scavenge low or high levels of nutrients quite efficiently from the environment (Caperon \& Meyer 1972, Eppley \& Renger 1974, Goldman \& McCarthy 1978, Lehman \& Scavia 1982), but the mechanisms by which, as well as the time scales over which, the material taken up is transformed into new biomass and/or new cells, are still far from well known. While uptake of silicate has been shown to be tightly coupled to cell division (Lewin 1962, Lewin et al. 1966, Darley et al. 1976, Sullivan 1977, Chisholm et al. 1978), this is certainly not the case for other nutrients such as nitrogen or phosphorus. The concept of balanced growth (Campbell 1957, Shuter 1979, Eppley 1981), which is implicit in studies of the assimilation of such compounds, has led some investigators to questionable conclusions regarding the significance of rapid uptake 
rates in relation to algal growth in a nutrient-depleted environment. For example, McCarthy \& Goldman (1979) implicitly assume an instantaneous response of growth rate to cell quota increases when extrapolating their laboratory results to the field situation. Such an assumption may not always be true, because time delays are sometimes involved in the relation between those parameters (Caperon 1969, Cunningham \& Nisbet 1978, 1980, Gotham \& Rhee 1981, Quarmby et al. 1982).

The use of several steady states to characterize the relation between uptake and growth (McCarthy \& Goldman 1979, Goldman \& Glibert 1982) makes this relation independent of time. Information on the time scale required to transform nitrogen or phosphorus taken up into new cells or biomass is crucial to reach conclusions concerning the possible mechanisms of survival in a nutrient-poor and probably patchy area. Nevertheless, the hypothesis presented by McCarthy \& Goldman (1979) certainly stimulated further work on internal nutrient pools by noting that 'research is needed in which $Q$ (cell quota) is partitioned into nutrient storage and active metabolic pools'. Later investigations have shown that, in the case of nitrogen uptake, many intermediate compounds can accumulate intracellularly after nitrogen is supplied to algal cells (Collos \& Slawyk 1980, Collos 1982, Dortch 1982, Dortch et al. 1984) and before cell division occurs. Such phenomena complicate the interpretation of uptake data as the resulting increase in cell quota does not necessarily imply an equivalent increase in cell numbers or in nutritional value for higher trophic levels. For example, Collos \& Slawyk (1977) have shown that up to $90 \%$ of the nitrate taken up over $6 \mathrm{~h}$ by natural phytoplankton in upwelling areas can be found inside the cells as unreduced nitrate. More recently, Wheeler et al. (1982) observed that uptake of ammonium during short-term incubations probably represents only internal ammonium labeling, and that longer incubations are required to obtain rates of macromolecular synthesis.

Thus, the problem of relating nutrient uptake rate to cell growth defined as increases in cell numbers is essential for a good understanding of primary production (Legendre et al. 1984). It is, however, a particularly difficult problem because cell division is a discontinuous function, while nutrient uptake can be considered as a continuous one, even if non-linear phenomena are associated with it (Collos 1983). Such a distinction between nutrient uptake and cell division is particularly important for limiting nutrients and in non steady-state situations which are now thought to be the rule in the oceans (Dugdale 1977, McCarthy 1981, Goldman $1984 a, b)$. This review presents data on the relation between nutrient uptake (mostly inorganic nitrogen and phosphorus) under transient conditions and phytoplankton growth, as measured by increases in cell numbers, and puts the high nutrient uptake rates of algal cells recently reported into physiological (if not ecological) perspective.

The literature on phytoplankton growth under transient nutritional conditions was surveyed in order to quantify the time delays involved in the growth response of cells to a new supply of the limiting nutrient. Starting from the reasonable assumption that algal cells in oligotrophic areas may be periodically depleted or starved of nitrogen or phosphorus, published experiments on the effect of resupply of ammonium, nitrate or phosphate to nitrogen $(\mathrm{N})$ or phosphorus (P)-depleted or starved cells in algal cultures have been used. Most of these experiments were not originally designed to study the lag between nutrient uptake and cell growth, and some of them did not even measure the uptake of the added nutrient. They could nevertheless be used for the present purpose because the relevant parameter was the time elapsed between a change in the nutrient regime and the beginning of growth as estimated from increases in cell numbers.

Nitrate was also considered here because, even though this compound is not relevant to the current micropatch nutrient debate, such data are of importance in stratified oceanic areas where deep nutrient supply may be of a pulsed nature (Klein \& Coste 1984).

Nutrient starvation was generally reached in batch cultures either by letting cells deplete the $N$ or $P$ source during the course of growth (Ketchum 1939, Spencer 1954, Thomas \& Dodson 1968, Eppley \& Thomas 1969, Finenko \& Krupatkina-Akinina 1974, Dortch 1982), or by washing and transferring cells to new medium lacking $N$ or $P$ (Yentsch \& Vaccaro 1958, Eppley \& Thomas 1969, Guérin-Dumartrait et al. 1970 , Berland et al. 1973). The term 'starved' refers to the absence of an essential nutrient such as $N$ or $P$ and, even though some studies did not actually measure nutrient levels, it could be estimated from mass balance that the nutrients in question were indeed depleted by the cells at the time of the experiment. Sometimes, the nutritional status was estimated from intracellular parameters, such as in the study of Berland et al. (1973) where it was obvious from carbon-tonitrogen composition ratios that the cells were not $N$ depleted at the beginning of the experiments. Therefore, data were selected on the basis of the evolution of particulate nitrogen ( $P N$ ) or protein concentration, i.e. only when the PN or the protein stopped increasing were the cells considered as starved. This corresponded roughly to the depletion of the $\mathrm{N}$ source supplied by the culture inoculum in the above study

The following equivalences between names of algal 
species which have changed have been used: Thalassiosira pseudonana clone $13-1=T$. oceanica; Thalassiosira fluviatilis $=T$. weissflogi, Exuviella mariae-lebourae = Prorocentrum minimum; Gymnodinium splendens $=G$. sanguineum; Asterionella japonica $=$ A. glacialis; Anacystis $s p$. = Synechococcus sp. The second name, which is the more recent one, will be used throughout this paper.

Vmax is defined as the maximum specific uptake rate in units of time ${ }^{-1} ;$ Pmax is the maximum absolute uptake rate in units of mass cell ${ }^{-1}$ time $^{-1}$.

\section{CHOICE OF GROWTH PARAMETER: RESULTING VARIABILITY IN LAG ESTIMATES UNDER TRANSIENT NUTRIENT CONDITIONS}

Table 1 illustrates that growth lag may vary considerably depending on the parameter chosen to assess 'growth'. For example, the lag in growth following $\mathrm{N}$ resupply to $\mathrm{N}$-starved cells of Skeletonema costatum or Pavlova luther ranges from zero when growth is estimated from increases in particulate nitrogen (PN) to $48 \mathrm{~h}$ when cell numbers are used, with intermediate

Table 1. Variations in estimates of growth lags as a function of the parameter chosen to measure algal growth

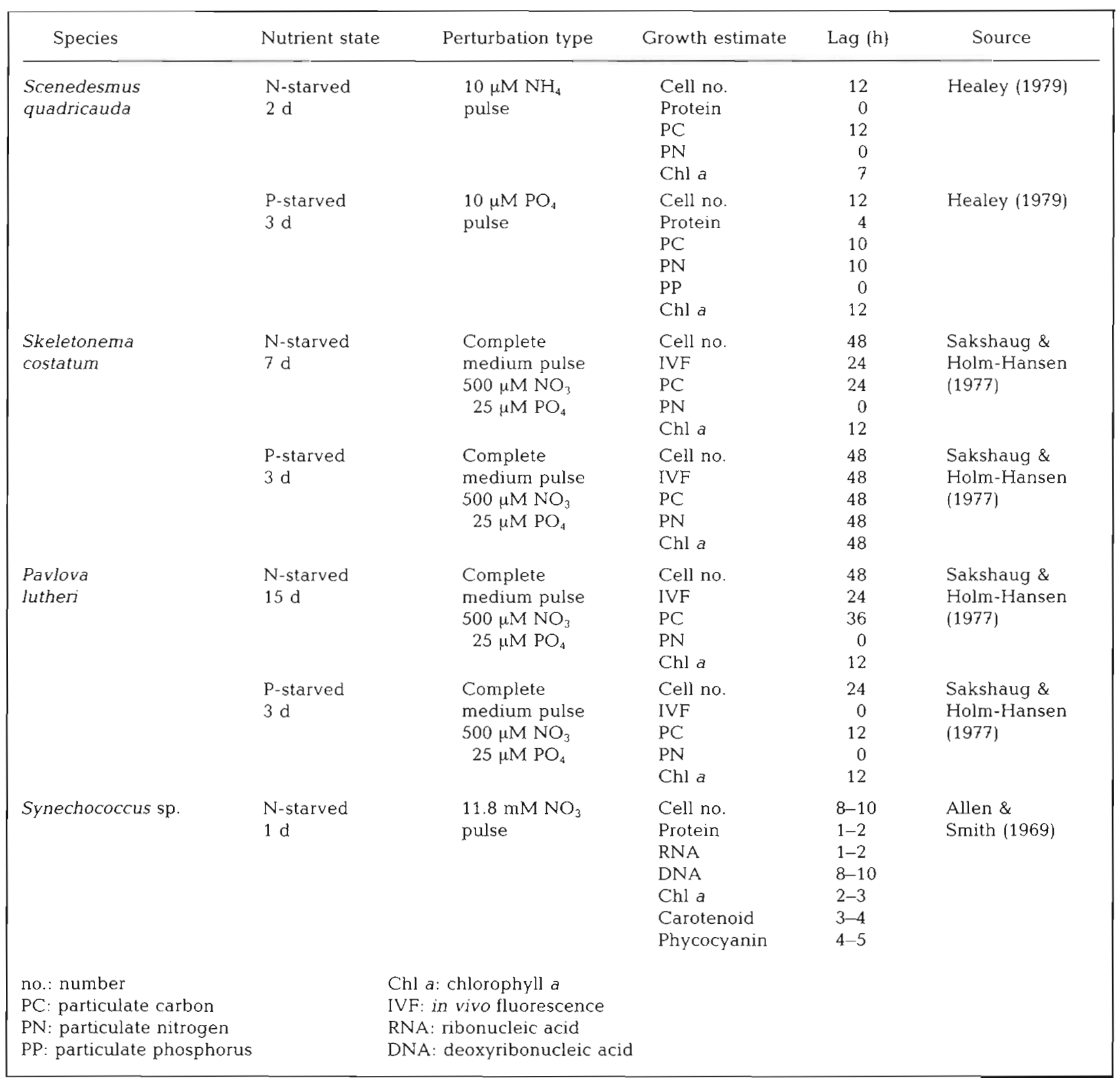


values when using particulate carbon $(\mathrm{PC})$, in vivo fluorescence (IVF) or chlorophyll a (Sakshaug \& HolmHansen 1977). This study, as well as that of Healey (1979) and Allen \& Smith (1969) - all of which have used at least 5 different parameters to estimate algal growth under transient conditions - show that growth lag is greatest when the cell numbers are used. This applies to ammonium, nitrate and phosphate additions as well. The above examples also show that - for phytoplankton in a varying nutrient regime, i.e. any situation other than steady-state in a chemostat culture - the estimate of growth can vary from zero to any value depending on the chosen parameter. In a similar way, conclusions on species competition may vary considerably depending on whether nutrient uptake or cell division is considered as an estimate of phytoplankton growth. In the remainder of the paper, the term 'growth' will therefore be defined as reproduction of cells by binary fission.

\section{LAGS IN CELL DIVISION: INFLUENCE OF SPECIES AND NUTRIENT PULSE MAGNITUDE}

Tables 2, 3 and 4 summarize published data on the delay involved between a resupply of nutrient and the change in cell numbers. The lags observed here are different from the well-known lag phase in cell division following transfers of batch cultures to fresh medium (Fogg 1971). The main difference lies in the fact that cells used in the experiments presented here are starved of a particular compound: $\mathrm{N}$ or $\mathrm{P}$.

Under identical experimental conditions, the time lag can be quite variable, ranging from zero for Dunaliella tertiolecta to more than $24 \mathrm{~h}$ for Thalassiosira pseudonana and Amphidinium carterae (Dortch et al. 1984) for ammonium pulses (Table 2), and from zero for Chaetoceros lauderi to $72 \mathrm{~h}$ for Skeletonema costatum, Prorocentrum minimum and Chlamydomonas magnusii (Berland et al. 1973) for nitrate pulses (Table 4). Species of the genus Chaetoceras stand out as being able to grow rapidly following a phosphate (Table 3) or a nitrate (Table 4) pulse. The same can be said of Dunaliella following an ammonium (Table 2) or nitrate (Table 4) pulse. In contrast to those, species such as $T$. pseudonana exhibit growth lags of $24 \mathrm{~h}$ or more after an ammonium (Table 2 ) or nitrate (Table 4) pulse.

Additional data from Olson \& Chisholm (1983) could not be presented under the chosen table format because their experiments are more sophisticated than those in Table 2. Essentially, they supplied a single ammonium pulse to $\mathrm{N}$-limited cells of unicellular algae at different times of the L-D cycle. For Hymenomonas carterae and Amphidinium carterae, cell division patterns were controlled more by the photocycle than by the ammonium pulse; the reverse was true for Thalassiosira weissflogii.

In the case of phosphate uptake, Nyholm (1978) differentiated between phosphate pulses (about

Table 2. Time lag between ammonium resupply to $\mathrm{N}$-starved cells and beginning of growth estimated from cell counts

\begin{tabular}{|c|c|c|c|c|c|}
\hline Species & $\begin{array}{c}\text { Duration of } \\
\text { starvation (h) }\end{array}$ & Light regime & $\begin{array}{l}\text { Perturbation } \\
\text { type }\end{array}$ & $\operatorname{Lag}(\mathrm{h})$ & Source \\
\hline $\begin{array}{l}\text { Scenedesmus } \\
\text { quadricauda }\end{array}$ & 48 & $24 \mathrm{~L}$ & $\begin{array}{l}10 \mu \mathrm{M} \\
\text { pulse }\end{array}$ & 12 & Healey (1979) \\
\hline $\begin{array}{l}\text { Platymonas } \\
\text { striata }\end{array}$ & 24 & $\begin{array}{l}24 \mathrm{~L} \text { or } \\
16 \mathrm{~L}-8 \mathrm{D}\end{array}$ & $\begin{array}{l}714 \mu \mathrm{M} \\
\text { pulse }\end{array}$ & $>24$ & $\begin{array}{l}\text { Edge \& Ricketts } \\
(1977)\end{array}$ \\
\hline $\begin{array}{l}\text { Isochrysis } \\
\text { galbana }\end{array}$ & 72 & $24 \mathrm{~L}$ & $\begin{array}{l}50 \mu \mathrm{M} \\
\text { pulse }\end{array}$ & 9 & $\begin{array}{l}\text { Dortch et al. } \\
(1984)\end{array}$ \\
\hline $\begin{array}{l}\text { Dunaliella } \\
\text { tertiolecta }\end{array}$ & 72 & $24 \mathrm{~L}$ & $\begin{array}{l}10 \mu \mathrm{M} \\
\text { pulse }\end{array}$ & 0 & $\begin{array}{l}\text { Dortch et al. } \\
\text { (1984) }\end{array}$ \\
\hline $\begin{array}{l}\text { Amphidinium } \\
\text { carterae }\end{array}$ & 72 & $24 \mathrm{~L}$ & $\begin{array}{l}10 \mu \mathrm{M} \\
\text { pulse }\end{array}$ & $>26$ & $\begin{array}{l}\text { Dortch et al. } \\
(1984)\end{array}$ \\
\hline $\begin{array}{l}\text { Skeletonema } \\
\text { costatum }\end{array}$ & 72 & $24 \mathrm{~L}$ & $\begin{array}{l}10 \mu \mathrm{M} \\
\text { pulse }\end{array}$ & 4 & $\begin{array}{l}\text { Dortch et al. } \\
\text { (1984) }\end{array}$ \\
\hline $\begin{array}{l}\text { Thalassiosira } \\
\text { pseudonana }\end{array}$ & 72 & $24 \mathrm{~L}$ & $\begin{array}{l}10 \mu \mathrm{M} \\
\text { pulse }\end{array}$ & $>24$ & $\begin{array}{l}\text { Dortch et al. } \\
\text { (1984) }\end{array}$ \\
\hline $\begin{array}{l}\text { Thalassiosira } \\
\text { nordenskioldii }\end{array}$ & 72 & $24 \mathrm{~L}$ & $\begin{array}{l}10 \mu \mathrm{M} \\
\text { pulse }\end{array}$ & 8 & $\begin{array}{l}\text { Dortch et al. } \\
(1984)\end{array}$ \\
\hline $\begin{array}{l}\text { N: nitrogen } \\
\text {. light hours } \\
\text { : dark hours }\end{array}$ & & & & & \\
\hline
\end{tabular}


$15 \mu \mathrm{M}$ ) and phosphate shocks (above $150 \mu \mathrm{M}$ ) and observed, along with Burmaster (1979) that the latter seemed to inhibit algal growth estimated from cell numbers. While reductions in growth rates following $\mathrm{N}$ pulses are sometimes due to methodological artefacts (Plumley \& Darley 1985), unquestionable dramatic changes in cell integrity can occur under such circumstances. For example, considerable losses of cellular matter due to protoplasm lysis during spermatogenesis induced by recovery from $\mathrm{N}$ starvation have been observed in a Stephanopyxis sp. (Stosch \& Drebes 1964) and in Skeletonema costatum (Sakshaug \& Holm-Hansen 1977).

An important feature resulting from the compilation is the lack of effect of the $\mathrm{N}$ source on the growth lag. Although $\mathrm{N}$-starved cells are known to exhibit enhanced ammonium uptake and depressed nitrate uptake (Dortch et al. 1982), the difference between the effect of these $2 \mathrm{~N}$ sources at the level of cell division is nil, as, for example, Skeletonema costatum exhibited an identical time lag ( $4 \mathrm{~h}$ ) in cell division after addition of ammonium or nitrate (compare Table 2 and 4, data from Dortch et al. 1984). The same phenomenon was observed in cultures of Cylindrotheca fusiformis (Plumley \& Darley 1985).

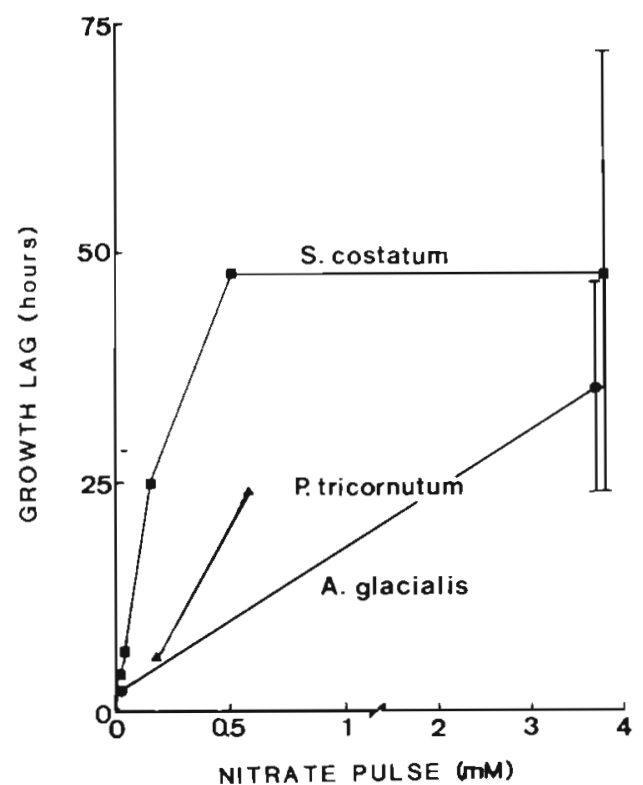

Fig. 1 Effect of magnitude of a single nitrate pulse on growth lag of N-starved cells of 3 diatoms. Data from Yentsch \& Vaccaro (1958), Carlucci et al. (1970), Berland et al. (1973), Sakshaug \& Holm-Hansen (1977), Dortch et al. (1984). Vertical bars: range of values obtained on 4 different strains of Skeletonema costatum by Berland et al. (1973)

Table 3. Time lag between phosphate resupply to P-starved cells and beginning of growth estimated from cell counts

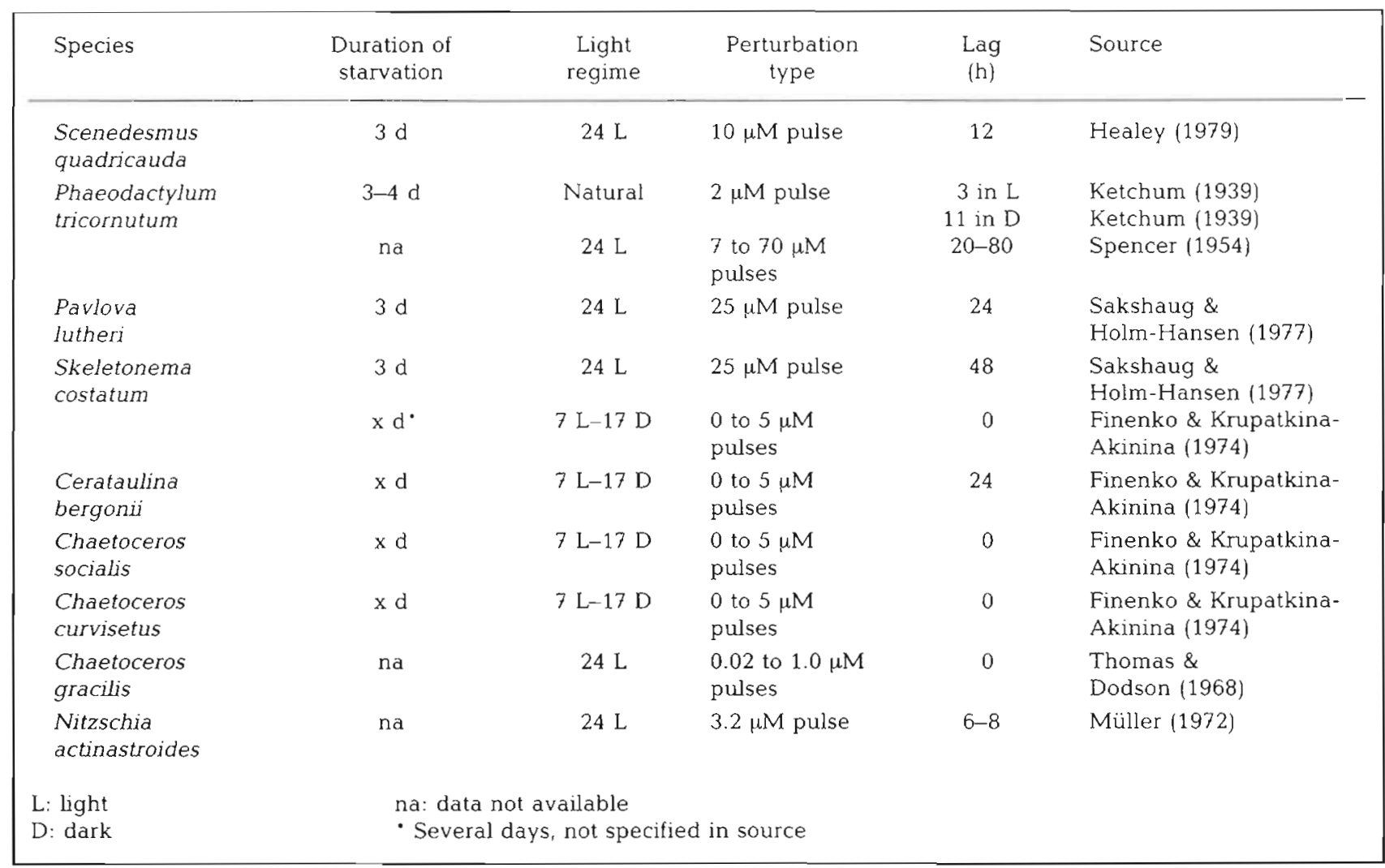


Growth lag can sometimes be related to the magnitude of the nutrient pulse. Fig. $1 \& 2$ illustrate such a relation for 3 diatoms which had been initially $N$ or $\mathrm{P}$ starved. The consistency of the relation shown in Fig. 1 and concerning Skeletonema costatum is striking in view of the fact that data were obtained from 5 different sources, implying varying experimental conditions. For example, temperature ranged from $17^{\circ} \mathrm{C}$ (Dortch et al. 1984) to $20^{\circ} \mathrm{C}$ (Carlucci et al. 1970) and starvation from $1 \mathrm{~d}$ (Berland et al. 1973) to 7 days (Sakshaug \& Holm-Hansen 1977). Additional data on Thalassiosira weissflogii (Yoder et al. 1982) presented the same trends (4 and $10 \mathrm{~h}$ lags for 1.7 and $20 \mu \mathrm{M}$ pulses respectively), but was not shown for the sake of clarity. Concerning ammonium, Plumley \& Darley (1985) observed that the lag in cell division of $\mathrm{N}$ limited Cylindrotheca fusiformis increased with the magnitude of ammonium additions. Fig. 3 shows growth lag of 4 species of unicellular algae as a function of ammonium pulses. In this particular case (Thomas et al. 1980), cells were not $\mathrm{N}$-depleted, but these data were retained because they exemplify the interspecific variability in response to ammonium pulses. Some species, such as Gonyaulax polyedra and

Table 4. Time lag between nitrate resupply to $\mathrm{N}$-starved cells and beginning of growth estimated from cell counts

\begin{tabular}{|c|c|c|c|c|c|}
\hline Species & $\begin{array}{l}\text { Duration of } \\
\text { starvation }\end{array}$ & Light regime & Perturbation type & $\operatorname{Lag}(\mathrm{h})$ & Source \\
\hline $\begin{array}{l}\text { Chlorella } \\
\text { pyrenoidosa }\end{array}$ & $4 \mathrm{~d}$ & $14 \mathrm{~L}-100$ & $\begin{array}{l}\text { Complete } \\
\text { medium added }\end{array}$ & 8 & $\begin{array}{l}\text { Guérin-Dumartrait } \\
\text { et al. (1970) }\end{array}$ \\
\hline \multirow[t]{2}{*}{$\begin{array}{l}\text { Phaeodactylum } \\
\text { tricornutum }\end{array}$} & $4 \mathrm{~d}$ & $24 \mathrm{~L}$ & $192 \mu \mathrm{M}$ pulse & 6 & $\begin{array}{l}\text { Yentsch \& } \\
\text { Vaccaro (1958) }\end{array}$ \\
\hline & $1 \mathrm{~d}$ & $24 \mathrm{~L}$ & $588 \mu \mathrm{M}$ pulse & 24 & $\begin{array}{l}\text { Berland et al. } \\
\text { (1973) }\end{array}$ \\
\hline $\begin{array}{l}\text { Platymonas } \\
\text { striata }\end{array}$ & $1 \mathrm{~d}$ & $24 \mathrm{~L}$ & $714 \mu \mathrm{M}$ pulse & $>24$ & $\begin{array}{l}\text { Edge \& Ricketts } \\
(1977)\end{array}$ \\
\hline $\begin{array}{l}\text { Chlamydomonas } \\
\text { magnusii }\end{array}$ & $1 \mathrm{~d}$ & $24 \mathrm{~L}$ & $3800 \mu \mathrm{M}$ pulse & $24-72$ & $\begin{array}{l}\text { Berland et al. } \\
\text { (1973) }\end{array}$ \\
\hline $\begin{array}{l}\text { Monallantus } \\
\text { salina }\end{array}$ & $1 \mathrm{~d}$ & $24 \mathrm{~L}$ & $3800 \mu \mathrm{M}$ pulse & 72 & $\begin{array}{l}\text { Berland et al. } \\
(1973)\end{array}$ \\
\hline $\begin{array}{l}\text { Prorocentrum } \\
\text { minimum }\end{array}$ & $1 \mathrm{~d}$ & $24 \mathrm{~L}$ & $3800 \mu \mathrm{M}$ pulse & $24-72$ & $\begin{array}{l}\text { Berland et al. } \\
\text { (1973) }\end{array}$ \\
\hline $\begin{array}{l}\text { Asterionella } \\
\text { glacialis }\end{array}$ & $1 \mathrm{~d}$ & $24 \mathrm{~L}$ & $3800 \mu \mathrm{M}$ pulse & $24-48$ & $\begin{array}{l}\text { Berland et al. } \\
(1973)\end{array}$ \\
\hline $\begin{array}{l}\text { Chaetoceros } \\
\text { lauderi }\end{array}$ & $1 \mathrm{~d}$ & $24 \mathrm{~L}$ & $3800 \mu \mathrm{M}$ pulse & 0 & $\begin{array}{l}\text { Berland et al. } \\
(1973)\end{array}$ \\
\hline \multirow[t]{5}{*}{$\begin{array}{l}\text { Skeletonema } \\
\text { costatum (4 strains) }\end{array}$} & $24 \mathrm{~h}$ & $24 \mathrm{~L}$ & $3800 \mu \mathrm{M}$ pulse & $24-72$ & $\begin{array}{l}\text { Berland et al. } \\
\text { (1973) }\end{array}$ \\
\hline & $36 \mathrm{~h}$ & $24 \mathrm{~L}$ & $150 \mu \mathrm{M}$ pulse & 24 & $\begin{array}{l}\text { Carlucci et al. } \\
(1970)\end{array}$ \\
\hline & $36 \mathrm{~h}$ & $24 \mathrm{~L}$ & $50 \mu \mathrm{M}$ pulse & 12 & $\begin{array}{l}\text { Carlucci et al. } \\
(1970)\end{array}$ \\
\hline & $7 \mathrm{~d}$ & $24 \mathrm{~L}$ & $500 \mu \mathrm{M}$ pulse & 48 & $\begin{array}{l}\text { Sakshaug \& } \\
\text { Holm-Hansen (1977) }\end{array}$ \\
\hline & $72 \mathrm{~h}$ & $24 \mathrm{~L}$ & $10 \mu \mathrm{M}$ pulse & 4 & $\begin{array}{l}\text { Dortch et al. } \\
(1984)\end{array}$ \\
\hline $\begin{array}{l}\text { Thalassiosira } \\
\text { pseudonana }\end{array}$ & $72 \mathrm{~h}$ & $24 \mathrm{~L}$ & $10 \mu \mathrm{M}$ pulse & $>34$ & $\begin{array}{l}\text { Dortch et al. } \\
\text { (1984) }\end{array}$ \\
\hline $\begin{array}{l}\text { Dunaliella } \\
\text { tertiolecta }\end{array}$ & $72 \mathrm{~h}$ & $24 \mathrm{~L}$ & $10 \mu \mathrm{M}$ pulse & 0 & $\begin{array}{l}\text { Dortch et al. } \\
\text { (1984) }\end{array}$ \\
\hline $\begin{array}{l}\text { Amphidinium } \\
\text { carterae }\end{array}$ & $72 \mathrm{~h}$ & $24 \mathrm{~L}$ & $10 \mu \mathrm{M}$ pulse & $>26$ & $\begin{array}{l}\text { Dortch et al. } \\
(1984)\end{array}$ \\
\hline $\begin{array}{l}\text { Thalassiosira } \\
\text { weissflogii }\end{array}$ & $10 \mathrm{~h}$ & $12 \mathrm{~L}-12 \mathrm{D}$ & $\begin{array}{l}1.7 \mu \mathrm{M} \text { pulse } \\
20.0 \mu \mathrm{M} \text { pulse }\end{array}$ & $\begin{array}{r}4 \\
10\end{array}$ & $\begin{array}{l}\text { Yoder et al. } \\
(1982)\end{array}$ \\
\hline $\begin{array}{l}\text { Pavlova } \\
\text { lutheri }\end{array}$ & $15 \mathrm{~d}$ & $12 \mathrm{~L}-12 \mathrm{D}$ & $500 \mu \mathrm{M}$ pulse & 48 & $\begin{array}{l}\text { Sakshaug \& } \\
\text { Holm-Hansen (1977) }\end{array}$ \\
\hline \multicolumn{6}{|l|}{ L: light hours } \\
\hline
\end{tabular}




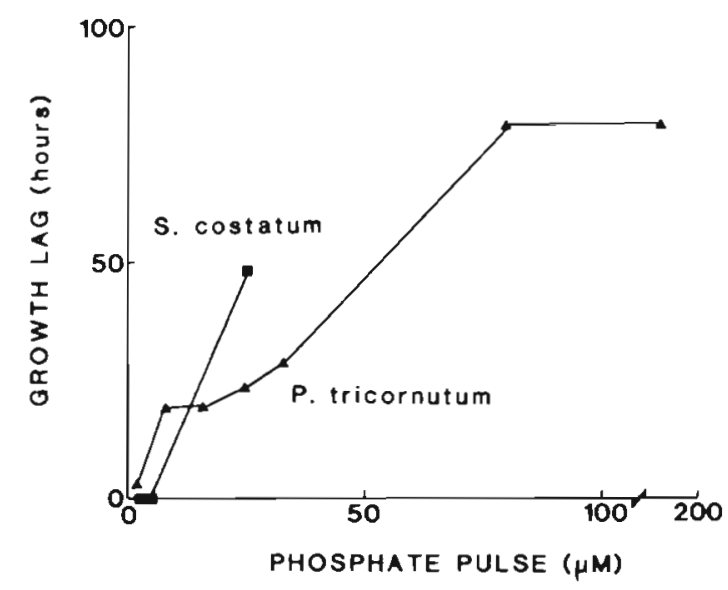

Fig. 2. Effect of magnitude of a single phosphate pulse on growth lag of phosphate-starved cells of 2 diatoms. Data from Ketchum (1939), Spencer (1954), Finenko \& KrupatkinaAkinina (1974), Sakshaug \& Holm-Hansen (1977)

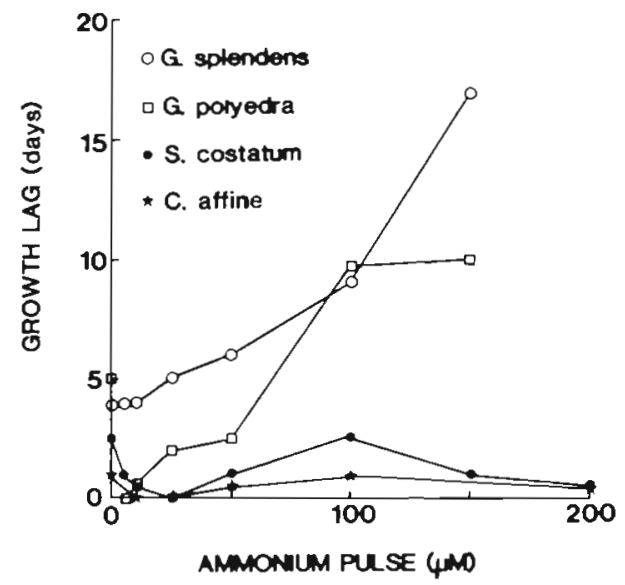

Fig. 3. Effect of magnitude of a single ammonium pulse on growth lag of several phytoplankters. Data from Thomas et al. (1980). Final growth rate was not significantly different from controls. Data on Dunaliella tertiolecta and Asterionella glacialis not shown (see text)

Gymnodinium sanguineum, are very sensitive to large ammonium pulses, while others, such as $S .{ }^{\prime}$ costatum and Chaetoceros affine, adapt much faster to similar perturbations in the nutrient regime. Dunaliella tertiolecta and Asterionella glacialis were also tested in the same study. The first species exhibited no lag in growth rate whatever the magnitude of the pulse and the second species presented $24 \mathrm{~h}$ lags only at ammonium pulses above $50 \mu \mathrm{M}$.

It may be argued that the range of concentrations presented in Fig. 1 to 3 is not realistic. Nutrient data in micropatches or marine aggregates are few. Shanks \& Trent (1979) reported maximum values of about 500, 300 and $80 \mu \mathrm{M}$ for ammonium, nitrate and phosphate respectively in marine micropatches. These values

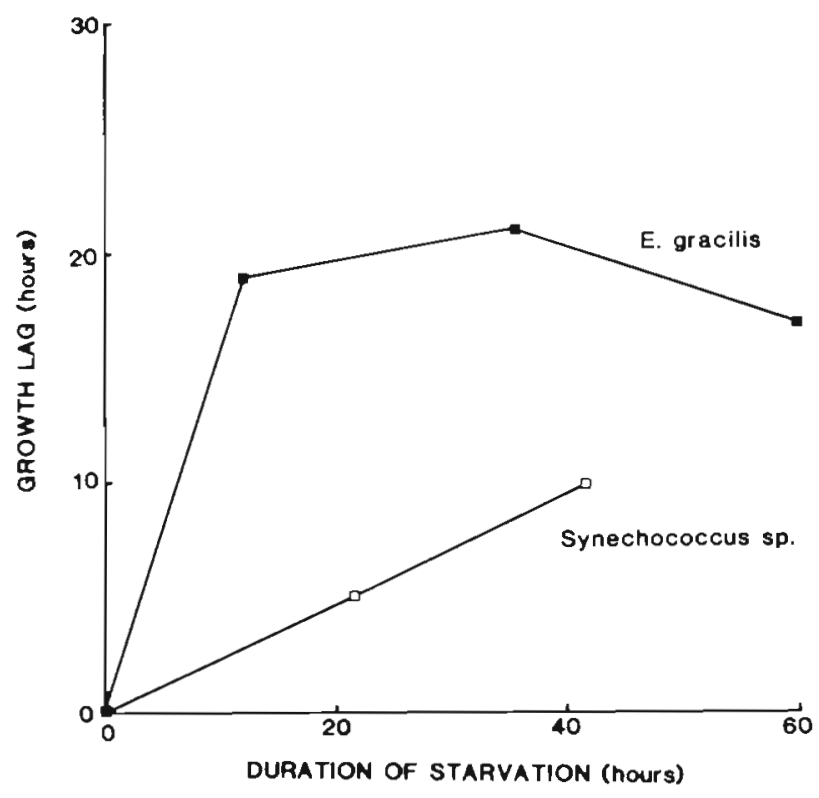

Fig. 4. Effect of duration of phosphate starvation on growth lag of 2 unicellular algae upon resupply of phosphate. Data from Buetow \& Schuit (1968) and Ihlenfeldt \& Gibson (1975)

indicate that, at least for Fig. 2 and 3, the concentrations used are relevant to the natural situation. Moreover, the values reported by Shanks \& Trent may have to be revised upwards as they were measured on samples volumes which are too large to be considered as relevant to phytoplankton spatial scales (Allen 1977. Harris 1980).

Finally, growth lag was found to be related to the duration of starvation (Fig. 4), either with a saturation effect or not. Such patterns were expected, but starvation duration does not seem to be a major factor in phytoplankton growth dynamics as its influence was clearly overriden by that of the pulse magnitude for Skeletonema costatum, Phaeodactylum tricornutum and Asterionella glacialis (Fig. 1), all of which were in various nutritional states. The importance of this effect does not seem to have been recognized so far and will need to be included in modelling studies of algal competition.

\section{UPTAKE AND GROWTH: QUANTITATIVE RELATIONS}

The examples shown above indicate that, for most algal species, transformation of material taken up into new biomass is not instantaneous, but requires a certain amount of time which varies among species. For some of them, the lag in cell division is so extensive that uptake and growth do not belong to the same time domains. For example, Thalassiosira weissflogii takes 
up nitrate during the first $12 \mathrm{~h}$ after resupply and divides during the following $12 \mathrm{~h}$ (Yoder et al. 1982). $\mathrm{N}$-starved T. nordenskioldii cells do not start dividing before exhaustion $(7 \mathrm{~h})$ of the supplied ammonium pulse (Dortch et al. 1984). Amphidinium carterae exhausts a $10 \mu \mathrm{M}$ ammonium pulse in $6 \mathrm{~h}$, but starts dividing only more than $26 \mathrm{~h}$ after the pulse (Dortch et al. 1982, 1984). Those different time scales have important implications on the interpretation of nutrient uptake rates in terms of algal growth rate estimates, as well as on the outcome of competition between species for limiting nutrients

The first to deal in quantitative terms with the relation between uptake and growth in unicellular algae were probably Eppley \& Thomas (1969). Using diatoms grown in batch cultures, they showed that uncoupling of uptake and growth could occur in $\mathrm{N}$-starved (Chaetoceros gracile) and $\mathrm{N}$-sufficient (Asterionella glacialis) cells. Caperon \& Meyer (1972) tried to establish a relationship between growth rate $(\mu)$ and the maximum uptake rate using phytoplankters grown in steady-state continuous cultures. Although observing a great variability in response to pulses depending on the species and units used to express the rates, they concluded that Vmax increased with $\mu$. Later work by Eppley \& Renger (1974) and McCarthy \& Goldman (1979) revealed the opposite trend, i.e. that Vmax decreased with increasing growth rate. Collos \& Slawyk (1980) tried to reconcile the contradictory data sets and suggested a bell-shaped relation between the nutrient supply rate and Vmax (Fig. 5) already apparent in some of Caperon \& Meyer's (1972) data and in data from Healey (1978) and Burmaster \& Chisholm (1979) on phosphate uptake (Fig. 6) and associated

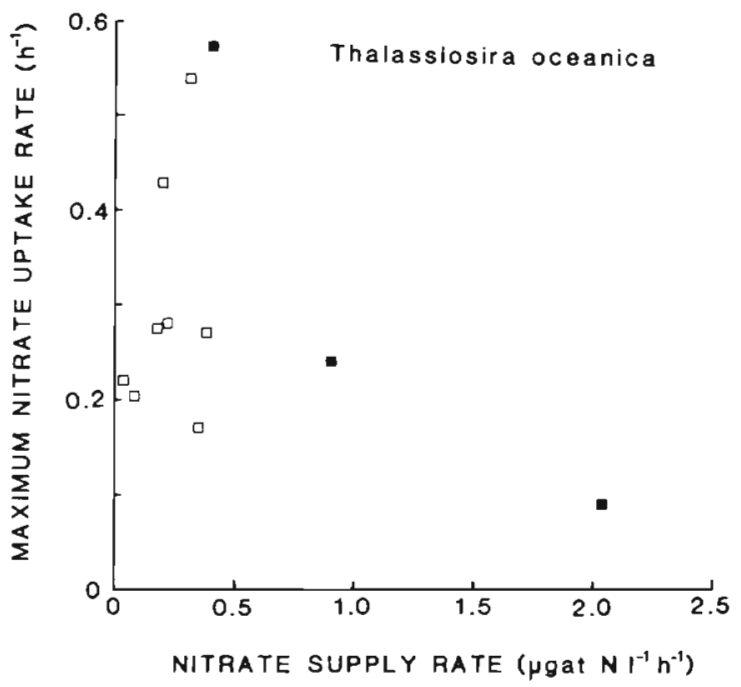

Fig. 5. Maximum nitrate uptake rate as a function of nutrient supply rate in chemostat culture. Data from Caperon \& Meyer (1972) ( $\square$ ), and Eppley \& Renger (1974) (

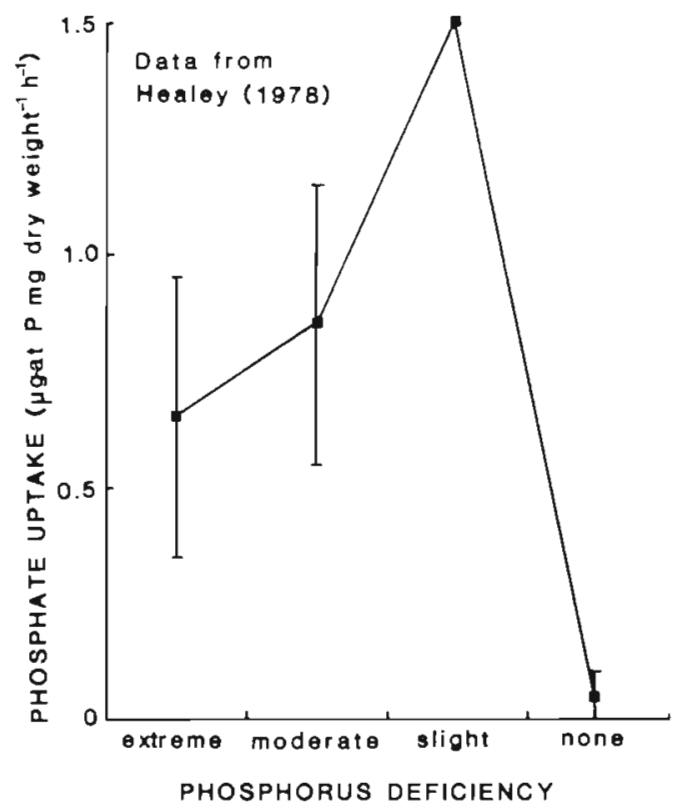

Fig. 6. Phosphate uptake as a function of phosphate deficiency. Data from Healey (1978) on a variety of unicellular algae. Vertical bars: range of values obtained on different species

enzyme activities. Goldman \& Glibert (1982) experimentally confirmed such a relation for Thalassiosira pseudonana and several other species, but disagreed with Collos \& Slawyk (1980) on which part of the curve best represents the natural situation in oligotrophic oceans. In their argumentation, McCarthy \& Goldman (1979) and Goldman \& Glibert (1982) selected data showing an inverse relation between ammonium uptake rate and algal growth rate (dilution rate of the continuous culture). They extrapolated such data to the field, essentially saying that phytoplankters in oligotrophic areas are able to grow fast because they can take up limiting nutrients very rapidly. Thus, the implicit assumption here is that the growth response is at least as fast as the fluctuations in limiting nutrient levels.

In the case of McCarthy \& Goldman (1979), the example of Thalassiosira pseudonana was ill chosen because more recent work has shown that $\mathrm{N}$-starved cells of this species present time lags of more than $24 \mathrm{~h}$ between an ammonium pulse and the beginning of cell division (Dortch et al. 1984). But, even if an instantaneous response of growth rate to a nutrient pulse can be assumed, the data of McCarthy \& Goldman (1979) suggest that high uptake rates and high growth rates are mutually exclusive. Although this inconsistency was demonstrated by modelling studies (Turpin et al. 1981) and is beginning to be recognized (Goldman 1984a), it has not yet been suggested that a direct relationship between those 2 parameters could be of 
advantage to a phytoplankter in a nutrient-poor and patchy area.

\section{UPTAKE-GROWTH UNCOUPLING, INTERNAL NUTRIENT POOLS AND GROWTH LAGS}

In this context, it might be of interest to establish a parallel between data sets concerning the uncoupling between $V \max$ and $\mu$, and those on accumulation of inorganic $\mathrm{N}$ internal pools and growth lag following a limiting nutrient pulse. Although data are lacking for certain species, it appears that those whose uptake and growth are highly coupled, such as species of Dunaliella or Chaetoceros (Goldman \& Glibert 1982) accumulate very little internal inorganic N (Fig. 7) and exhibit a short growth lag (Fig. 8). These species may then process nutrient pulses into new biomass very efficiently. In contrast, algae such as Thalassiosira weissflogii and Amphidinium carterae can accumulate large amounts of ammonium (Conover 1975, Wheeler et al. 1983, Dortch et al. 1984) and present extensive uncoupling between uptake and growth (Goldman \& Glibert 1982) and large growth lags upon $N$ resupply (Dortch et al. 1984). This distinction is similar to the one made by microbiologists (Bader 1982) for substrate-limited growth: assimilative control when growth is limited by the uptake rate, and physiological control when it is limited by the rate of conversion of soluble substrates into biomass.

The relation between uptake-growth uncoupling and the internal ammonium pool (Fig. 7) could be logically expected. Indeed, it reveals a rather remarkable consistency in view of the fact that the 2 sets of variables were obtained by different groups of investigators. In contrast, the interpretation of the relation between the maximum internal ammonium pool and the growth lag is more difficult, and the arrangement of the axes as shown in Fig. 8 should not be taken to imply a cause-effect relation. Note, however, that such data are consistent with those of Fig. 3 in that species such as Dunaliella, Chaetoceros and Skeletonema presented very reduced lags upon ammonium pulses in the study of Thomas et al. (1980), and that the low ammonium content of Chaetoceros cells is also consistent with the absence of ammonium surge uptake in this genus (Conway \& Harrison 1977). Thus, coming back to the relation between $V \max$ and $\mu$, it can be seen from the case of Chaetoceros (Fig. $7 \&$ 8), that a direct relation between uptake and growth can be of advantage in a nutrient-poor environment. Goldman \& Glibert (1982) disregarded such a possibility, but it must be recognized that such a relation has the advantage of liberating us from the paradox which is apparent in the hypothesis of McCarthy \& Goldman (1979)

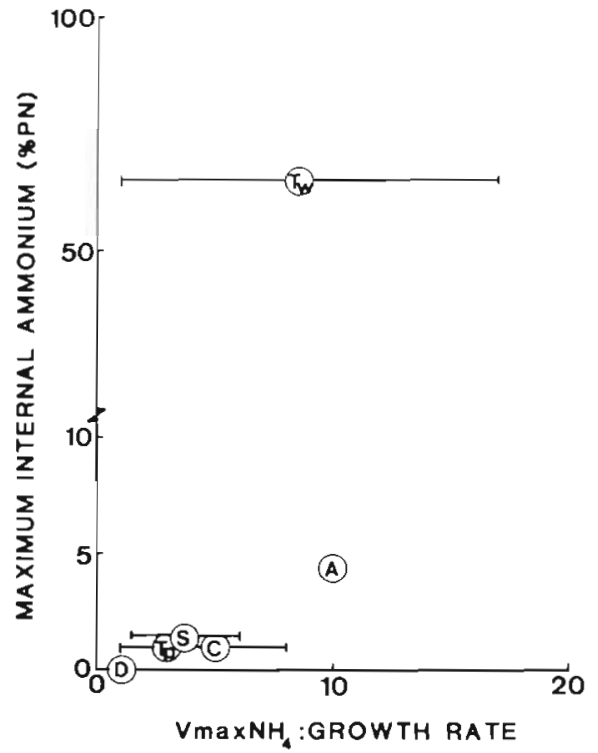

Fig. 7. Maximum internal ammonium pool as a function of the uncoupling between maximum uptake rate and steady-state growth rate. D: Dunaliella; S: Skeletonema; C: Chaetoceros; A: Amphidinium; Tp: Thalassiosira pseudonana $3 \mathrm{H}$; $\mathrm{Tw}$ : Thalassiosira weissflogii. Data from Eppley \& Thomas (1969), Conover (1975), Conway et al. (1976), Conway \& Harrison (1977). Collos \& Slawyk (1979), Dortch et al. (1982, 1984), Goldman \& Glibert (1982), Thoresen et al. (1982). Horizontal bars: range of values found by different authors, or by the same authors under varying conditions

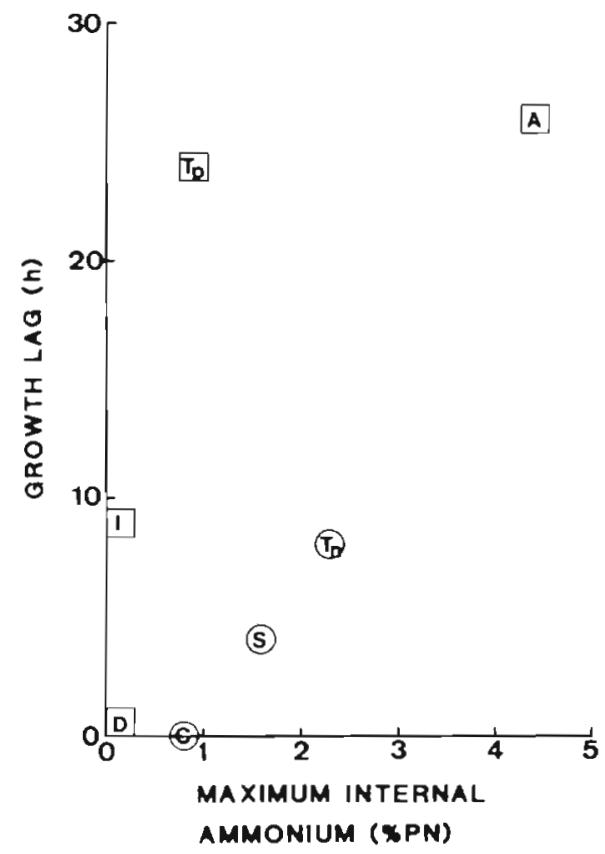

Fig. 8. Growth $\operatorname{lag}$ as a function of the maximum internal ammonium pool. A: Amphidinium; C: Chaetoceros; D: DunaLiella; I: Isochrysis; S: Skeletonema; Tn: Thalassiosira nordenskioldii; Tp: Thalassiosira pseudonana $3 \mathrm{H}$. Data from Berland et al. (1973), Thoresen et al. (1982), Dortch et al. (1984). For A and Tp, growth lag values are minimum values 
involving an inverse relation between $\mu$ and $V$ : either the phytoplankton grows fast and has low uptake rates, or it grows slowly, and exhibits high uptake rates. Caperon (1969) and Caperon \& Meyer (1972) suggested that the ability to accumulate internal stores of limiting nutrients was an ecological advantage in a nutrient patchy area. This might be true when the frequency of encounters with elevated nutrient areas is lower than the frequency of cell division, such as might be the case for nitrate pulses, for example, whose period has been shown to be of the order of $48 \mathrm{~h}$ in stratified oceanic areas (Klein \& Coste 1984). However, if the nutrient pulsing frequency is high, as postulated in the current regenerated nutrient micropatch hypothesis (McCarthy \& Goldman 1979, Lehman \& Scavia 1982, 1984, Goldman 1984a, b), then I would suggest that growth rate has to be coupled to nutrient uptake rate for phytoplankton to survive in nutrientpoor waters. Any growth lag will be a disadvantage in terms of cell numbers.

For example, Fig. 8 indicates that, for $10 \mu \mathrm{M}$ ammonium pulses (used by Dortch et al. 1984), Chaetoceros would become dominant over Skeletonema costatum and Thalassiosira nordenskioldii at pulsing frequencies greater than 1 per $4 \mathrm{~h}$ ( $4 \mathrm{~h}$ being the minimum growth lag of $S$. costatum on the ordinate of Fig. 8), because the latter 2 species would not have time enough to divide before the next pulse. This result is contrary to what Turpin \& Harrison $(1979,1980)$ found, but may be explained by the lower ammonium pulses in their culture systems (a single $3 \mu \mathrm{M}$ pulse every $24 \mathrm{~h}$, or a $0.38 \mu \mathrm{M}$ pulse every $3 \mathrm{~h}$ ). Their conclusions and the ordering of the 3 above species as a function of ammonium pulsing frequency might well vary also as a function of the pulse magnitude, and the induced cell division lag.

\section{NUTRIENT PULSES AND INORGANIC CARBON UPTAKE}

In the microbiological literature, various causes of lag phases have been recorded (Barford et al. 1982). In the present case, interactions between $\mathrm{C}$ and $\mathrm{N}$ metabolism could be added to this list. Carbon is the main element in living matter after hydrogen, and any perturbation of its exchange between the cell and the environment is likely to have major consequences on subsequent growth and cell division. Transient changes in net $\mathrm{C}$ uptake following limiting nutrient pulses are presently the subject of much debate (Collos \& Slawyk 1984, Elrifi \& Turpin 1985, Goldman \& Dennett 1985), but it appears that they depend on light levels and species. Data from Natarajan (1970) and Thomas et al. (1980) illutrate very clearly the influ-

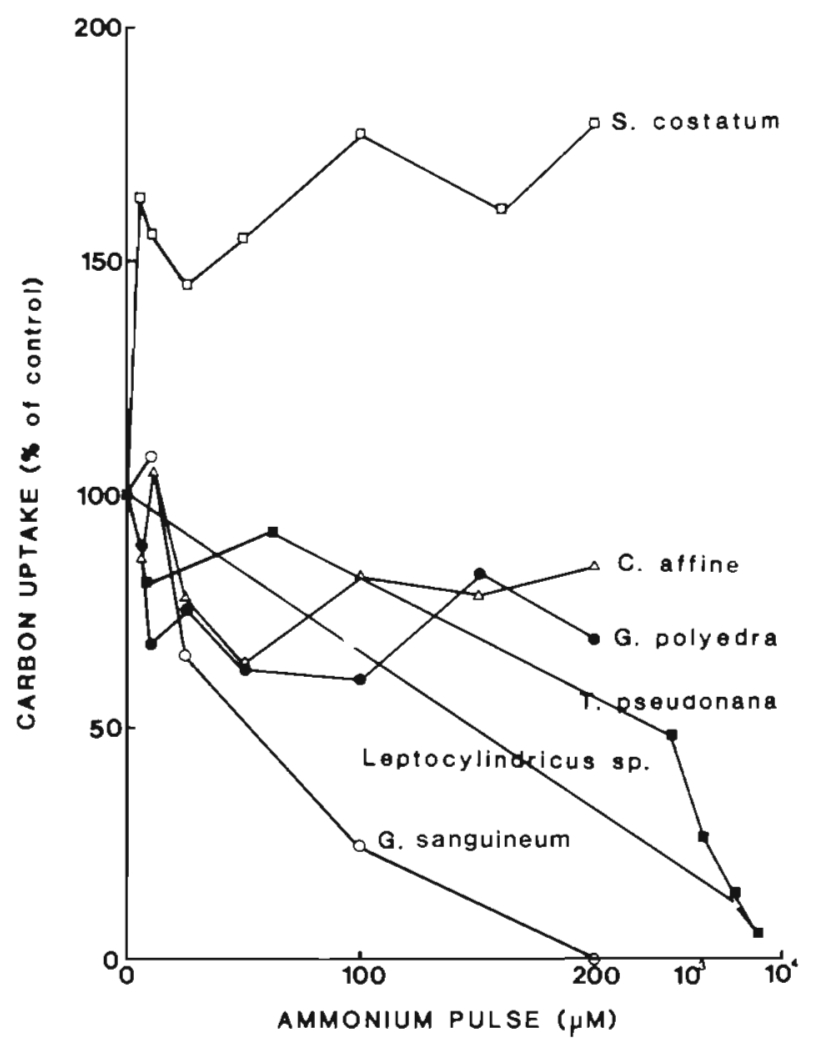

Fig. 9. Effect of varying concentrations of a single ammonium pulse on net carbon uptake by 6 species of phytoplankters.

Data from Natarajan (1970) and Thomas et al. (1980)

ence of ammonium pulses on net $\mathrm{C}$ uptake in 6 species of phytoplankters (Fig. 9). In particular, the inhibition (Thalassiosira pseudonana) or stimulation (Skeletonema costatum) of the $\mathrm{C}$ uptake system by ammonium pulses is consistent with the large or reduced growth lags respectively exhibited by these species (Dortch et al. 1984)

Reduction in net carbon uptake upon ammonium pulses was interpreted as evidence for toxicity by Natarajan (1970) and Thomas et al. (1980). It could also represent an adaptation (Stockner \& Antia 1976) in the form of a transient response which is later followed by a stimulation in $\mathrm{C}$ uptake such as observed by Turpin (1983).

Apart from the fact that such effects have a very practical impact on estimates of primary production based on $\mathrm{C}$ uptake, it remains that, in the case of Thalassiosira pseudonana, far-reaching consequences were observed on cell division which took place only $24 \mathrm{~h}$ after the ammonium spike (Dortch et al. 1984). Former studies on nutrient pulsing in algal cultures (Quarmby et al. 1982) have shown a peak in C fixation $14 \mathrm{~h}$ after ammonium addition. Transient changes in net $\mathrm{C}$ uptake have also been observed following phosphate pulses to phytoplankton (Becacos 1962, Stross et 
al. 1973, Stross \& Pemrick 1974, Lean \& Pick 1981). Thus, the assumption of uncoupling between nutrient uptake and photosynthesis necessary to rapid growth and sporadic nutrient uptake (Goldman et al. 1981) is not always supported by experimental data.

\section{NUTRIENT PULSES AND BALANCED GROWTH}

Absence of a time lag for Dunaliella and Chaetoceros in Tables 2, 3 and 4 does not necessarily imply an instantaneous response of growth rate to an increase in nutrient supply, but probably reflects the inadequate sampling frequency for cell number determinations. While immediate increases in $\mathrm{PN}$ or IVF are possible upon $\mathrm{N}$ resupply (Table 1), this is certainly not the case for cell numbers, and there are good physiological reasons for this. The simplest of these is that phytoplankton cells, like all biological material, are made not only of $N$ or $P$, but also of other elements and of macromolecules. For example, in the cell model of Williams (1971), a distinction is made between a 'synthetic' portion, consisting mostly of soluble nutrient pools, chlorophyll and enzymes, and a 'structural/genetic' portion consisting mainly of genetic material, cell wall and membranes. An idea of the minimum lag in cell division for transient conditions can be obtained from the microbiological literature where values of about 1 h have been recorded following a nutritional shift-up imposed on bacterial cultures (Kjeldgaard et al. 1961, Kjeldgaard 1958, Mateles et al. 1965, Schleif 1967). This represents the time necessary for DNA synthesis and chromosome replication. In spite of such evidence, it appears that, so far, most reasoning concerning $\mathrm{N}$-based growth rates have considered only the synthetic (or storage) portion of the cell. For example, McCarthy \& Goldman (1979), Goldman \& Glibert (1982), and Goldman (1984b) argue that the presence of micropatches of nutrients allow maximum growth rates to be reached by algal cells. The results presented here indicate that several constraints other than the one outlined by, for example, Goldman (1984b) appear. First is the magnitude of the nutrient pulse. If we assume as a starting point that the algal cells are $\mathrm{N}$-limited or starved (an assumption made by McCarthy \& Goldman 1979), we can see that the encounter of a $3000 \mu \mathrm{M}$ ammonium pulse (postulated in the study of Goldman $1984 \mathrm{~b}$ ), will reduce the net $\mathrm{C}$ uptake of Thalassiosira pseudonana by about $80 \%$ (Fig. 9) for as long as 6 to $7 \mathrm{~h}$. Generally, nutrient pulses of this magnitude have been found to inhibit, rather than enhance algal growth (Nyholm 1978, Burmaster 1979).

Thus, it appears that, at least for some species, there occurs a considerable cellular rearrangement follow- ing nutrient pulses and that, in some cases, a large amount of time (more than $24 \mathrm{~h}$ ) may be needed in order to resume balanced growth and before cell division occurs.

The second constraint which is likely to potentially reduce the $\mathrm{N}$ uptake-based growth rate is the decrease of Vmax with time. Collos (1983) has reviewed patterns of uptake as a function of time under conditions of substrate saturation for nitrate and ammonium. Concerning the latter, and on time scales shorter than either the generation time of the organisms involved or the diurnal changes in environmental conditions such as the light-dark periodicity, the vast majority of species exhibited rapid decreases in Vmax following an ammonium pulse.

Such uptake patterns necessitate the use of appropriate time units in expressing observed rates. For example, if ammonium uptake is measured over a $1 \mathrm{~min}$ period, the uptake rate should be reported in units of $\min ^{-1}$ and not $\mathrm{h}^{-1}$ unless the constancy of uptake with time is established. In the same way, extrapolations of growth rates from uptake rates should be made only under conditions of balanced growth (Eppley \& Strickland 1968).

A final constraint to primary production estimated from limiting nutrient uptake is that cell division may be restricted to a particular portion of the day-night cycle regardless of the nutrient regime (Wheeler et al. 1983).

It is probably too early to try to extend the laboratory results to the natural situation. Data on nutrient pulse magnitude and frequency in the field are clearly needed in order to assess primary production on relevant time scales. While such data are becoming available for nitrate (Klein \& Coste 1984), they are still very scarce for other forms of dissolved N (Legendre et al. 1985, Smith 1986). The results presented here, however, are in agreement with Turpin \& Harrison $(1979,1980)$ and Lehman \& Scavia (1984) in that nutrient pulses should have marked effects on species composition.

For the time being, we have to rely on algal culture data in order to help interpret field results and gain insight into phytoplankton growth processes. These data show that there are transient effects of nutrient pulses on growth of nutrient-limited or starved algae, the most spectacular of these being the induced time lag in cell division. The fact that these effects can be either inhibiting or stimulating on growth processes has very practical consequences, both on estimates of primary production from $\mathrm{C}$ uptake and interpretations of limiting nutrient uptake rates measured over short periods of time. Concerning the latter, I suggest following Williams (1971) - that, until we have a more complete understanding of the significance of limiting nutrient uptake relative to algal growth, uptake data lead not to extrapolations of growth rate in the particu- 
late phase, but to values of 'nutrient demand', i.e. changes in the dissolved phase of aquatic environments.

Acknowledgements. Support for this research came from the Centre National de la Recherche Scientifique and the Institut Français de Recherche pour l'Exploitation de la Mer (UM 10). I thank P. J. Harrison, J. Lewin, E. Paasche and A. Sournia for comments.

\section{LITERATURE CITED}

Allen, M. N., Smith, A. J. (1969). Nutrient chlorosis in bluegreen algae. Arch. Mikrobiol. 69: 114-120

Allen, T. F. H. (1977). Scale in microscopic algal ecology: a neglected dimension. Phycologia 16: 253-257

Bader, F. B. (1982). Kinetics of double-substrate limited growth. In: Bazin, M. J. (ed.) Microbial population dynamics. CRC Press, Boca Raton, p. 1-32

Barford, J. P., Pamment, N. B., Hall, R. J. (1982). Lag phases and transients. In: Bazin, M. J. (ed.) Microbial population dynamics. CRC Press, Boca Raton, p. 55-89

Becacos, T. (1962). Azione di alcune sostanze inorganiche sull' attività fotosintetica in due laghi dell'alta Italia (Lago Maggiore e Lago di Mergozzo). Memorie Ist. ital. Idrobiol. 15: $45-68$

Berland, B. R., Bonin, D. J., Maestrini, S. Y., Pointier, J. P. (1973). Etude de la fertilité des eaux marines au moyen de tests biologiques effectués avec des cultures d'algues. II. Limitation nutritionnelle et viabilité de l'inoculum. Int. Rev. ges. Hydrobiol. 58: 203-220

Buetow, D. E., Schuit, K. E. (1968). Phosphorus and the growth of Euglena gracilis. J. Protozool. 15: 770-773

Burmaster, D. E. (1979). The unsteady continuous culture of phosphate-limited Monochrysis lutheri Droop: experimental and theoretical analysis. J. exp. mar. Biol. Ecol. 39: $167-186$

Burmaster, D. E., Chisholm, S. W. (1979). A comparison of two methods for measuring phosphate uptake by Monochrysis lutheri Droop grown in continuous culture. J. exp. mar. Biol. Ecol. 39: 187-202

Campbell, A. (1957). Synchronization of cell division. Bact. Rev. 21: 263-272

Caperon, J. (1969). Time lag in population growth response of Isochrysis galbana to a variable nitrate enviroment. Ecology 50: 188-192

Caperon, J., Meyer, J. (1972). Nitrogen-limited growth of marine phytoplankton. II. Uptake kinetics and their role in nutrient limited growth of phytoplankton. Deep Sea Res. 19: 619-632

Carlucci, A. F., Hartwig, E. O., Bowes, P. M. (1970). Bıological production of nitrite in seawater. Mar. Biol. 7: 161-166

Chisholm, S. W., Azam, F., Eppley, R. W (1978). Silicic acid incorporation in marine diatoms on light: dark cycles: use as an assay for phased cell division. Limnol. Oceanogr. 23: $518-529$

Collos, Y. (1982). Transient situations in nitrate assimilation by marine diatoms. III. Short-term uncoupling of nitrate uptake and reduction. J. exp. mar. Biol. Ecol. 62: 285-295

Collos, Y (1983). Transient situations in nitrate assimilation by marine diatoms. 4. Non-linear phenomena and the estimation of the maximum uptake rate. J. Plankton Res. 5: $677-691$

Collos, Y., Slawyk, G. (1977). Nitrate reductase activity as a function of in situ nitrate uptake and environmental fac- tors of euphotic zone profiles. J. exp. mar. Biol. Ecol. 29: $119-130$

Collos, Y., Slawyk, G. (1979). ${ }^{13} \mathrm{C}$ and ${ }^{15} \mathrm{~N}$ uptake by marine phytoplankton. I. Influence of nitrogen source and concentration in laboratory cultures of diatoms. J. Phycol. 15 186-190

Collos, Y., Slawyk, G. (1980). Nitrogen uptake and assimilation by marine phytoplankton. In: Falkowski, P. G. (ed.) Primary productivity in the sea. Plenum Press, New York p. $195-211$

Collos, Y., Slawyk, G. (1984). ${ }^{13} \mathrm{C}$ and ${ }^{15} \mathrm{~N}$ uptake by marine phytoplankton. III. Interactions in euphotic zone profiles of stratified oceanic areas. Mar Ecol. Prog. Ser. 19: 223-231

Conover, S. A. M. (1975). Partitioning of nitrogen and carbon in cultures of the marine diatom Thalassiosira fluviatilis supplied with nitrate, ammonium, or urea. Mar. Biol. 32: $231-246$

Conway, H. L., Harrison, P. J., Davis, C. O. (1976). Marine diatoms grown in chemostats under silicate or ammonium limitation. II. Transient response of Skeletonema costatum to a single addition of the limiting nutrient. Mar. Biol. 35: 187-199

Conway, H. L., Harrison, P. J. (1977). Marine diatoms grown in chemostats under silicate or ammonium limitation. IV Transient response of Chaetoceros debilis, Skeletonema costatum, and Thalassiosira gravida to a single addition of the limiting nutrient. Mar. Biol. 43: $33-43$

Cunningham, A., Maas, P. (1978). Time lag and nutrient storage effects in the transient growth response of Chlamydomonas reinhardii in nitrogen-limited batch and continuous culture. J. gen. Microbiol. 104: 227-231

Cunningham, A., Nisbet, R. M. (1980). Time lag and cooperativity in the transient growth dynamics of microalgae. J. theor. Biol. 84: 189-203

Currie, D. J. (1984a). Microscale nutrient patches: do they matter to the phytoplankton? Limnol. Oceanogr. 29: 211-214

Currie, D. J. (1984b). Phytoplankton growth and the microscale nutrient patch hypothesis. J. Plankton Res. 6: 591-599

Darley, W M., Sullivan, C. W., Volcani, B. E. (1976). Studies on the biochemistry and fine structure of silica shell formation in diatoms: division cycle and chemical composition of Navicula pelliculosa during light:dark synchronized growth. Planta 130: 159-167

Dortch, Q. (1982). Effect of growth conditions on accumulation of internal nitrate, ammonium, amino acids, and protein in three marine diatoms. J. exp. mar. Biol. Ecol. 61: 242-264

Dortch, Q., Clayton, J. R. Jr., Thoresen, S. S., Bressler, S. L., Ahmed, S. I. (1982). Response of marine phytoplankton to nitrogen deficiency: decreased nitrate uptake vs enhanced ammonium uptake. Mar. Biol. 70: 13-19

Dortch, Q., Clayton, J. R. Jr., Thoresen, S. S., Ahmed, S. I. (1984). Species differences in accumulation of nitrogen pools in phytoplankton. Mar Biol. 81: 237-250

Dugdale, R. C. (1977). Modeling. In: Goldberg, E. et al. (ed.) The sea, Vol. 6. Wiley-Interscience, New York, p. 789-808

Edge P. A., Ricketts, T R. (1977). The effect of nitrogen refeeding on the carbohydrate content of nitrogen-starved cells of Platymonas striata Butcher. Planta 136: 159-162

Elrifi, I. R., Turpin, D. H. (1985). Transient photosynthetic responses of nitrogen limited microalgae to nitrogen addition. Mar. Ecol. Prog. Ser 20: 253-258

Eppley, R. W (1981). Relations between nutrent assimilation 
and growth in phytoplankton with a brief review of estimates of growth rate in the ocean. In: Platt, T (ed.) Physiological bases of phytoplankton ecology. Can. Bull. Fish. Aquat. Sci. 210

Eppley, R. W., Renger, E. H. (1974). Nitrogen assimilation of an oceanic diatom in nitrogen-limited continuous culture. J. Phycol. 10: 15-23

Eppley, R. W., Strickland, J. D. H. (1968). Kinetics of marine phytoplankton growth. In: Droop, M., Ferguson Wood, E. J. (ed.) Advances in microbiology of the sea, Vol. 1. Academic Press, London, p. 23-62

Eppley, R. W., Thomas, W. H. (1969). Comparison of halfsaturation constants for growth and nitrate uptake of marine phytoplankton. J. Phycol. 5: 375-379

Finenko, Z. Z., Krupatkina-Akinina, D. K. (1974). Effect of inorganic phosphorus on the growth rate of diatoms. Mar. Biol. 26: 193-201

Fogg, G. E. (1971). Algal cultures and phytoplankton ecology. University of Wisconsin Press, Madison

Goldman, J. C. (1984a). Oceanic nutrient cycles. In: Fasham, M. J. R. (ed.) Flows of energy and materials in marine ecosystems, theory and practice. Plenum Press, New York, p. $137-170$

Goldman, J. C. (1984b). Conceptual role for microaggregates in pelagic waters. Bull. mar. Sci. $35: 462-476$

Goldman, J. C., Dennett, M. R. (1985). Photosynthetic responses of 15 phytoplankton species to ammonium pulsing. Mar. Ecol. Prog. Ser. 20: 259-264

Goldman, J. C., Dennett, M. R., Riley, C. B. (1981). Marine phytoplankton photosynthesis and transient ammonium availability. Mar. Biol. Lett. 2: 323-331

Goldman, J. C., Glibert, P. M. (1982). Comparative rapid ammonium uptake by four species of marine phytoplankton. Limnol. Oceanogr. 27: 814-827

Goldman, J. C., McCarthy, J. J. (1978). Steady-state growth and ammonium uptake of a fast-growing marine diatom. Limnol. Oceanogr 23: 695-703

Gotham, I. J., Rhee, G.-Y. (1981). Comparative kinetic studies of nitrate-limited growth and nitrate uptake in phytoplankton in continuous culture. J. Phycol. 17: 309-314

Guérin-Dumartrait, E., Mihara, S., Moyse, A. (1970). Composition de Chlorella pyrenoidosa, structure des cellules et de leurs lamelles chloroplastiques, en fonction de la carence en azote et de la levée de carence. Can. J. Bot. 48: $1147-1154$

Harris. G. P. (1980). Temporal and spatial scales in phytoplankton ecology. Mechanisms, methods, modéls, and management. Can. J. Fish. Aquat. Sci. 37: 877-900

Healey, F. P. (1978). Physiological indicators of nutrient deficiency in algae. Mitt. int. Verein. theor. angew. Limnol. 21: $34-41$

Healey, F. P. (1979). Short-term responses of nutrient-deficient algae to nutrient additions. J. Phycol. 15: 289-299

Ihlenfeldt, M. J. A., Gibson, J. (1975). Phosphate utilization and alkaline phosphatase activity in Anacystis nidulans (Synechococcus). Arch. Microbiol. 102: 23-28

Ketchum, B. H. (1939). The development and restoration of deficiencies in the phosphorus and nitrogen composition of unicellular plants. J. cell. comp. Physiol. 13: 373-381

Kjeldgaard, N. O. (1961). The kinetics of ribonucleic acidand protein formation in Salmonella typhimurium during the transition between different states of balanced growth. Biochim. Biophys. Acta 49: 64-76

Kjeldgaard, N. O., Maaloe, O., Schaechter, M. (1958). The transition between different physiological states during the balanced growth of Salmonella typhimurium. J. gen. Microbiol. 19: 607-616
Klein, P., Coste, B. (1984). Effects of wind-stress variability on nutrient transport into the mixed layer. Deep Sea Res. 31: 21-37

Lean, D. R. S., Pick, F. R. (1981). Photosynthetic response of lake plankton to nutrient enrichment: a test for nutrient limitation. Limnol Oceanogr 26: 1001-1019

Legendre, L., Collos, Y., Elbrächter, M., Fasham, M. J. R., Gieskes, W. W. C., Herbland, A., Holligan, P. M., Margalef, R., Perry, M. J., Platt, T., Sakshaug, E., Smith, D. F. (1984). Studies on marine autotrophs: recommendations for the 1980s. In: Fasham, M. J. R. (ed.) Flows of energy and materials in marine ecosystems. Plenum Publishing Corporation, New York, p. 629639

Legendre, L., Demers, S., Therriault, J. C., Boudreau, C. A. (1985). Tidal variations in the photosynthesis of estuarine phytoplankton isolated in a tank. Mar. Biol. 88: 301-309

Lehman, J. T., Scavia, D. (1982). Microscale patchiness of nutrients in plankton communities. Science 216: 729-730

Lehman, J. T., Scavia, D. (1984). Measuring the ecological significance of microscale nutrient patches. Limnol. Oceanogr. 29: 214-216

Lewin, J. C. (1962). Silicification. In: Lewin, R. E. (ed.) Physiology and biochemistry of algae. Academic Press, New York

Lewin, J. C., Reimann, B. E., Busby, W. F., Volcani, B. E. (1966). Silica shell formation in synchronously dividing diatoms. In: Cameron, I. L., Padilla, G. M. (ed.) Cell synchrony. Academic Press, New York, p. 169-188

Mateles, R. I., Ryu, D. Y., Yasuda, T. (1965). Measurement of unsteady state growth rates of micro-organisms. Nature, Lond. 5007: 263-265

McCarthy, J. J. (1981). The kinetics of nutrient utilization. In: Platt, T. (ed.) Physiological bases of phytoplankton ecology. Can. Bull. Fish. Aquat. Sci. 210: 211-233

McCarthy, J. J., Goldman, J. C. (1979). Nitrogenous nutrition of marine phytoplankton in nutrient-depleted waters. Science 203: 670-672

Müller, H. (1972). Wachstum und Phosphatbedarf von Nitzschia actinastoides (Lemm.) v. Goor in statischer und homokontinuierlicher Kultur unter Phosphatlimitierung. Arch. Hydrobiol. (Suppl.) 38: 399-484

Natarajan, K. V. (1970). Toxicity of ammonium to marine diatoms. J. Water Pollut. Control Fed. 42: R184-R190

Nyholm, N. (1978). Dynamics of phosphate limited algal growth: simulation of phosphate shocks. J. theor. Biol. 70 : 415-425

Olson, R. J., Chisholm, S. W. (1983). Effects of photocycles and periodic ammonium supply on three marine phytoplankton species. I. Cell division patterns. J. Phycol. 19: $522-528$

Plumley, F. G., Darley, W. M. (1985). Interactions of light/dark cycles and nitrogen pulses on the timing of cell division in the nitrogen-limited marine diatom Cylindrotheca fusiformis (Bacillariophyceae). J. Phycol. 21: 25-34

Quarmby, L. M., Turpin, D. H., Harrison, P. J. (1982). Physiological responses of two marine diatoms to pulsed additions of ammonium. J. exp. mar. Biol. Ecol. 63: 173-181

Sakshaug, E., Holm-Hansen, O. (1977). Chemical composition of Skeletonema costatum (Grev.) Cleve and Pavlova (Monochrysis) lutheri (Droop) Green as a function of nitrate-, phosphate-, and iron-limited growth. J. exp. mar. Biol. Ecol. 29: 1-34

Schleif, R. (1967). Control of production of ribosomal protein. J. molec. Biol. 27: 41-55

Shanks, A. L., Trent, J. D. (1979). Marine snow: microscale nutrient patches. Limnol. Oceanogr. 24: 850-854 
Shuter, B. (1979). A model of physiological adaptation in unicellular algae. J. theor. Biol. 78: 519-552

Smith, D. F. (1986). Small-scale spatial heterogeneity in dissolved nutrient concentrations. Limnol. Oceanogr. 31: $167-171$

Spencer, C. P. (1954). Studies on the culture of a marine diatom. J. mar. biol. Ass. U.K. 33: 265-290

Stockner, J. G., Antia, N. J. (1976). Phytoplankton adaptation to environmental stresses from toxicants, nutrients, and pollutants - a warning. J. Fish. Res. Bd Can. 33: 2089-2096

Stosch, H. von, Drebes, G. (1964). Entwicklungsgeschichtliche Untersuchungen an zentrischen Diatomeen. IV. Die Planktondiatomee Stephanopyxis turris - ihre Behandlung und Entwicklungsgeschichte. Helgoländer wiss. Meeresunters. 11: 209-257

Stross, R. G., Chisholm, S. W., Downing, T. A. (1973). Causes of daily rhythms in photosynthetic rates of phytoplankton. Biol. Bull. mar. biol. Lab., Woods Hole 145: 200-209

Stross, R. G., Pemrick, S. M. (1974). Nutrient uptake kinetics in phytoplankton: a basis for niche separation. J. Phycol. 10: $164-169$

Sullivan, C. W. (1977). Diatom mineralization of silicic acid. II. Regulation of $\mathrm{Si}(\mathrm{OH})_{4}$ transport rates during the cell cycle of Navicula pelliculosa. J. Phycol. 13: 86-91

Thomas, W. H., Dodson, A. N. (1968). Effects of phosphate concentration on cell division rates and yield of a tropical oceanic diatom. Biol. Bull. mar. biol. Lab., Woods Hole 134: 199-208

Thomas, W. H., Hastings, J., Fujita, M. (1980). Ammonium input to the sea via large sewage outfalls-Part 2: effects of ammonium on growth and photosynthesis of southern California phytoplankton cultures. Mar. Env. Res. 3: 291-296
Thoresen, S. S., Dortch, Q., Ahmed, S. I. (1982). Comparison of methods for extracting intracellular pools of inorganic nitrogen from marine phytoplankton. J. Plankton Res. 4: 695-704

Turpin, D. H. (1983). Ammonium induced photosynthetic suppression in ammonium limited Dunaliella tertiolecta (Chlorophyta). J. Phycol. 19: 70-76

Turpin, D. H., Harrison, P. J. (1979). Limiting nutrient patchiness and its role in phytoplankton ecology. J. exp. mar. Biol. Ecol 39: 151-166

Turpin, D. H., Harrison, P. J. (1980). Cell size manipulation in natural marine, planktonic, diatom communities. Can. J. Fish. Aquat. Sci. 37: 1193-1195

Turpin, D. H., Parslow, J. S., Harrison, P. J. (1981). On limiting nutrient patchiness and phytoplankton growth: a conceptual approach. J. Plankton Res. 3: 421-431

Wheeler, P. A., Glibert, P. M., McCarthy, J. J. (1982). Ammonium uptake and incorporation by Chesapeake Bay phytoplankton: short-term uptake kinetics. Limnol. Oceanogr 27: 1113-1128

Wheeler, P. A., Olson, R. J., Chisholm, S. W. (1983). Effects of photocycles and periodic ammonium supply on three marine phytoplankton species. II. Ammonium uptake and assimilation. J. Phycol. 19: 528-533

Williams, F. M. (1971). Dynamics of microbial populations. In: Patten, (ed.) Systems analysis and simulation in ecology, Vol. 1. Academic Press, New York, p. 197-267

Yentsch, C, S., Vaccaro, R. F. (1958). Phytoplankton nitrogen in the oceans. Limnol. Oceanogr. 3: 443-448

Yoder, J. A., Martin, J., Nill, A. (1982). Cell division periodicity and the nitrate environment of a marine diatom. Limnol. Oceanogr. 27: 352-357 